\title{
Purification and Characterization of a Novel $\alpha$-L-Fucosidase from Fusarium oxysporum Grown on Sludge
}

\author{
Toshihiro Yano, Kenji Yamamoto, Hidehiko KumagaI, \\ Tatsurokuro TochIKURA, * Tatsuo YoKOYAma, ** \\ Taiko SENO** and Hideo YAMAGUCHI** \\ Department of Food Science and Technology, Kyoto University, Kyoto 606, Japan \\ * Institute for Fermentation, Osaka, Yodogawa-ku, Osaka 532, Japan \\ ** Osaka Red Cross Blood Center, Jyoto-ku, Osaka 536, Japan
}

Received April 22, 1985

\begin{abstract}
A novel $\alpha$-L-fucosidase was found in the culture broth of Fusarium oxysporum isolated from a soil sample when the fungus was cultivated on a liquid active sludge hydrolyzate medium. The enzyme was not found in the culture broth of the fungus grown on glucose medium. The $\alpha$-Lfucosidase from the fungus was purified to homogeneity by polyacrylamide gel electrophoresis after ammonium sulfate fractionation and successive column chromatographies on DEAE-Sephadex A50, hydroxylapatite, Sephadex G-150 and Con A-Sepharose 4B. The molecular weight was estimated to be about 80,000 by gel filtration, and the optimum $\mathrm{pH}$ was found to be 4.5 . The enzyme was relatively stable in the $\mathrm{pH}$ range of $4 \sim 8$ and up to $45^{\circ} \mathrm{C}$ on $10 \mathrm{~min}$ incubation. The $\mathrm{Km}$ value for $p$-nitrophenyl $\alpha$-L-fucoside was $0.87 \mathrm{~mm}$. The enzyme showed a novel substrate specificity in that it could hydrolyze porcine mucin and blood group substances of human saliva besides nitrophenyl compounds. Such a specificity has not been found for any other $\alpha$-L-fucosidase from various sources.
\end{abstract}

At present, increasing surplus active sludge which is produced on the treatment of city sewage and plant drainage is becoming a social problem, because it is one of the great unutilizable biomasses. We have investigated ways of reusing surplus sludge with microorganisms. We took advantage of the abundant glycoconjugates in the sludge and tried to obtain useful glycosidases produced by microorganisms able to assimilate the sludge as a medium. During the screening of glycosidases capable of degrading complex carbohydrates, we found that a strain of fungus isolated from a soil sample produced a novel $\alpha$-L-fucosidase in the culture fluid. The fungus was identified as Fusarium oxysporum Schlechtendahl emend. Snyder and Hansen.

L-Fucose is a very important component of various oligo- and polysaccharides, and glycoconjugates. It is usually located on the nonreducing termini of the carbohydrate moieties of several biologically active molecules such as serum glycoproteins, immunoglobulins, submaxillary mucins and blood group substances. ${ }^{1)}$ It is also present in oligosaccharides of human milk, marine algae polysaccharides and plant gums. ${ }^{2)}$ This sugar moiety of some complex carbohydrates plays an important role in cellular recognition, the immune response, etc.

$\alpha$-L-Fucosidase (EC 3.2.1.51) has been found to release $\mathrm{L}$-fucose from these molecules by splitting the terminal $\alpha$-L-fucosidic linkage. All enzymes from various sources reported generally showed a narrow aglycon specificity. They seem to be classifiable into two types. One type comprises the microbial enzymes. The $\alpha$-L-fucosidases from Trichomonas foetus ${ }^{3)}$ Clostridium perfringens, ${ }^{4)}$ Aspergillus niger $^{5)}$ and Bacillus fulminans ${ }^{6)}$ were found to release fucose from blood group substances but did not hydrolyze simple nitrophenyl fucosides. They may be $\alpha-(1 \rightarrow 2)$-specific $L$ fucosidases. The enzyme from almond emul- 
$\sin ^{7)}$ also showed this type of specificity. On the other hand, the $\alpha$-L-fucosidases from mammalian tissues, ${ }^{8 \sim 10)}$ abalone $^{11)}$ and a marine gastropod $^{12)}$ readily hydrolyzed $p$-nitrophenyl $\alpha$-L-fucoside and also liberated fucose slowly from mucin, but seemed not to hydrolyze blood group substances.

Our fungal $\alpha$-L-fucosidase showed a novel substrate specificity in that it could hydrolyze both $p$-nitrophenyl $\alpha$-L-fucoside and blood group substances. This paper describes the purification and properties of the unique $\alpha-\mathrm{L}-$ fucosidase from Fusarium oxysporum isolated from soil which was grown on active sludge hydrolyzate as a medium.

\section{MATERIALS AND METHODS}

Preparation of the sludge hydrolyzate. Active sludge was obtained after waste treatment from a Japanese sake company. Its water content was about $85 \%$. The hydrolyzate of the active sludge as a specific medium for microorganisms was prepared according to the following procedure. Active sludge was added to an equal volume of $0.6 \mathrm{~N} \mathrm{NaOH}$ solution, and then the mixture was hydrolyzed by autoclaving it at $120^{\circ} \mathrm{C}(1.2 \mathrm{~atm})$ for $30 \mathrm{~min}$. It should be hydrolyzed with $0.3 \mathrm{~N} \mathrm{NaOH}$. After centrifugation at $10,000 \times g$ for $30 \mathrm{~min}$, the supernatant was dialyzed against tap water overnight and then lyophilized. $0.3 \mathrm{~N} \mathrm{HCl}$ solution was added to the lyophilized powder, and then the mixture was hydrolyzed by autoclaving it for $30 \mathrm{~min}$ again. The hydrolyzate was neutralized by adding $\mathrm{NaOH}$.

Microorganism. The fungal strain, S252, which was isolated from a soil sample under Musa basjoo sieb. in the botanical gardens of Kyoto University, was used throughout this investigation.

Cultivation. The fungus was cultured in a liquid medium composed of $2 \%$ sludge hydrolyzate, $\mathrm{pH} 7.0$. A loop of the spore suspension was inoculated into $5 \mathrm{ml}$ of the medium in a test tube. Cultivation was carried out at $28^{\circ} \mathrm{C}$ with shaking. The fungus was maintained on $2 \%$ sludge hydrolyzate-agar slants.

Enzyme assay. $\alpha$-L-Fucosidase activity was assayed using $p$-nitrophenyl $\alpha$-L-fucoside as substrate. The enzyme solution (30 to $50 \mu \mathrm{l}$ containing $5 \sim 10 \mu \mathrm{g}$ protein) was added to $0.25 \mathrm{ml}$ of $2 \mathrm{~mm}$ substrate dissolved in $50 \mathrm{~mm}$ sodium citrate buffer ( $\mathrm{pH}$ 4.5). After incubation for an appropriate time at $37^{\circ} \mathrm{C}, 1.75 \mathrm{ml}$ of $0.2 \mathrm{M}$ sodium borate buffer $(\mathrm{pH} 9.8)$ was added to terminate the reaction and the release of $p$-nitrophenol was determined at $400 \mathrm{~nm}$. With these conditions, an extinction coefficient of $1.77 \times 10^{4} \mathrm{M}^{-1} \mathrm{~cm}^{-113}$ ) was used to calculate the concentration of $p$-nitrophenol in assay mixtures. Other glycosidase activities were also assayed using the corresponding $p$-nitrophenyl glycosides as substrates according to the same procedure as for $\alpha$-L-fucosidase activity. One unit of the enzyme activity was defined as the amount of enzyme which released $1 \mu \mathrm{mol}$ of $p$-nitrophenol per min. The specific activity was expressed as units per mg of protein.

Materials. $p$-Nitrophenyl derivatives of sugars were purchased from Nakarai Chemicals Ltd. Hydroxylapatite was prepared according to the method of Tiselius et al. ${ }^{14)}$ Sephadex G-150 and G-200, and Concanavalin ASepharose 4B were obtained from Pharmacia Fine Chemicals Co. Porcine gastric mucin was obtained from Nakarai Chemicals Ltd. All other chemicals used were of the highest grade commercially available.

Analyses. Protein was determined by the method of Lowry et al. ${ }^{15)}$ with crystalline egg albumin as the standard. For chromatographic procedures, the protein content was estimated by measuring the absorbance at $280 \mathrm{~nm}$. The amount of free fucose was determined by the microdiffusion method ${ }^{16)}$ using a Conway chamber.

Gel electrophoresis. Polyacrylamide disc gel electrophoresis was performed by the method of Davis ${ }^{17)}$ with a $7.5 \%$ polyacrylamide gel and Tris-glycine buffer, $\mathrm{pH} 8.3$. Electrophoresis was carried out at a current of $2 \mathrm{~mA}$ per column and gels were stained for protein with Amido black.

Molecular weight determination. The molecular weight of the enzyme was estimated by gel filtration on a column of Sephadex G-200 $(1.0 \times 120 \mathrm{~cm})$ by the method of Andrews. ${ }^{18)}$ Elution was carried out with $10 \mathrm{~mm}$ potassium phosphate buffer ( $\mathrm{pH} 7.0$ ). Catalase (MW, 232,000), aldolase (MW, 158,000), bovine serum albumin (MW, 67,000), ovalbumin (MW, 45,000), chymotrypsinogen (MW, 25,000) and ribonuclease (MW, 13,700) were used as standard proteins

Hemagglutination inhibition test for serological activity. The soluble $\mathrm{H}$ blood group substance of human saliva was prepared as follows: human group $\mathrm{O}$ saliva was centrifuged and the supernatant was boiled for $10 \mathrm{~min}$. After centrifugation, $99 \%$ ethanol was added to the supernatant to $80 \%$. The precipitate was lyophilized and the resulting powder used as the soluble $\mathrm{H}$ group substance. The group $\mathrm{O}$ cell suspension was prepared as follows: $\mathrm{O}$ cells were washed with saline three times. After the last wash, the pellet was suspended to $3 \%$ in saline. The hemagglutination-inhibition test was carried out as follows. To $0.1 \mathrm{ml}$ of each serial dilution of an Ulex europaeus 
(anti-H lectin) extract solution was added $0.1 \mathrm{ml}$ of the $\mathrm{H}$ substance solution treated with varying numbers of units of the $\alpha$-L-fucosidase at $37^{\circ} \mathrm{C}$ for $2 \mathrm{hr}$, and the solutions were then incubated for $10 \mathrm{~min}$ at room temperature. Then, $0.2 \mathrm{ml}$ of the $3 \% \mathrm{O}$ cell suspension was added to each of the solutions. The $\mathrm{H}$ substance after decomposition by the enzyme no longer inhibited the anti-H activity of the lectin. Therefore, we could determine the degree of decomposition of the $\mathrm{H}$ substance by means of the hemagglutination-inhibition test.

\section{RESULTS}

\section{Morphological characteristics of the fungus}

The isolated fungus grew rapidly as a white aerial mycelium which soon became tinged with purple when it was grown on malt extract-agar (MA) medium containing $2 \%$ of malt extract, $2 \%$ of glucose, $0.1 \%$ of peptone and $2 \%$ of agar. The fungus grown on the above medium abundantly produced only single-celled, ellipsoidal, oval to kidney-shaped microconidia in false heads. On the other hand the fungus produced abundant sickle-shaped, thin-walled, 3 4 septate macroconidia, with an attenuated apical cell and a prominent foot cell, when it was grown on Czapek agar medium or corn meal agar medium (Fig. 1). Sometimes chlamydospores were formed sin- gly or in pairs in aerial hyphae and macroconidia, being either terminal or intercalary. Conidiophores were sparsely branched or unbranched, as short, lateral monophialides on hyphae (Fig. 1). The average size of microconidia was $5 \sim 14 \times 1.6 \sim 4 \mu \mathrm{m}$. The 3 -septate macroconidia averaged $24 \times 4 \sim 5.6 \mu \mathrm{m}$ in size. The growth rate on MA-agar medium plate was fairly rapid (about $6 \mathrm{~mm} /$ day) at $28^{\circ} \mathrm{C}$, but the fungus grew only slightly at $37^{\circ} \mathrm{C}$. The presence of chlamydospores, microconidia borne in false heads on simple short lateral monophialides and thin-celled, shickle-shaped. $3 \sim 4$ septate macroconidia are the most distinguishable characteristics of Fusarium oxysporum Schlechtendahl $1^{19 \sim 21)}$ with which the fungus described above was identified.

\section{Production of $\alpha$-L-fucosidase}

After the fungus had been cultivated in a liquid medium composed of $2 \%$ sludge hydrolyzate for 2 days, various glycosidase activities in the culture fluid were investigated. We found high $\alpha$-L-fucosidase activity and slight $\beta$ glucosidase and $\beta$-galactosidase activities. The latter was about one-eighth of the former. Then, the effect of the concentration of
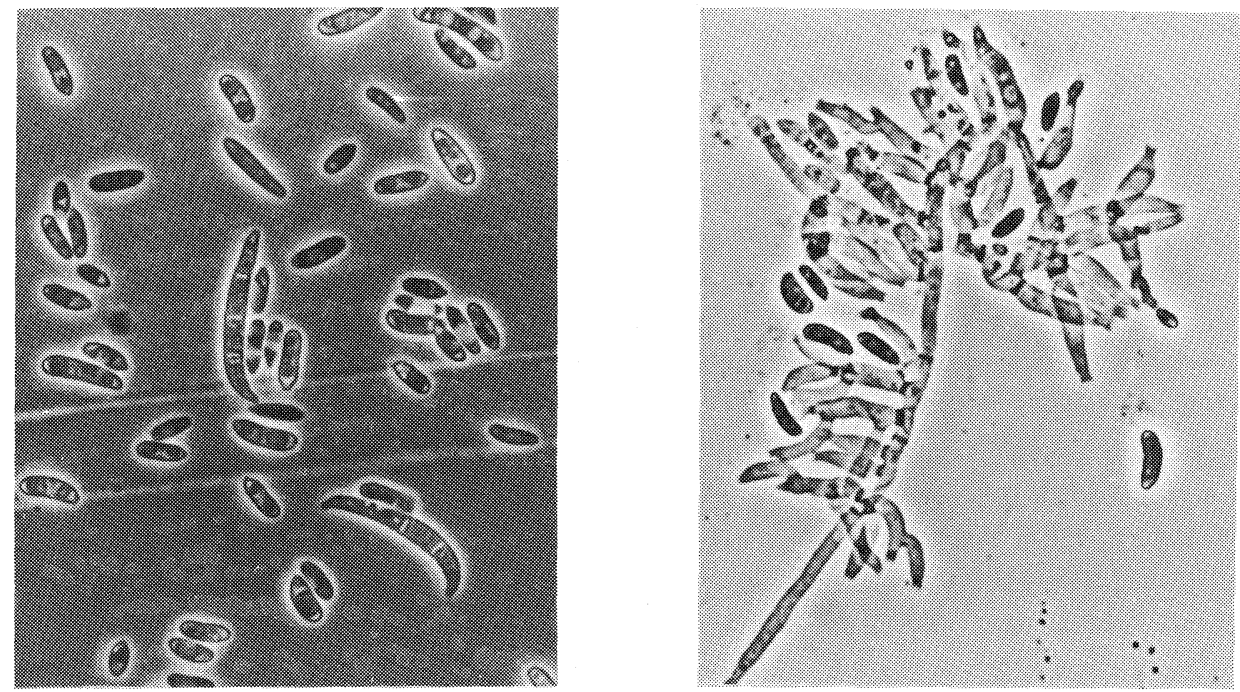

FIG. 1. Micrographs of Fusarium oxysporum Strain S252 Isolated from Soil.

(Left): Macroconidia (two sickled-shaped ones) and microconidia on corn meal agar medium.

(Right): Simple or sparsely branched, short, lateral monophialides on a mycelium on sludge hydrolyzate agar medium. 


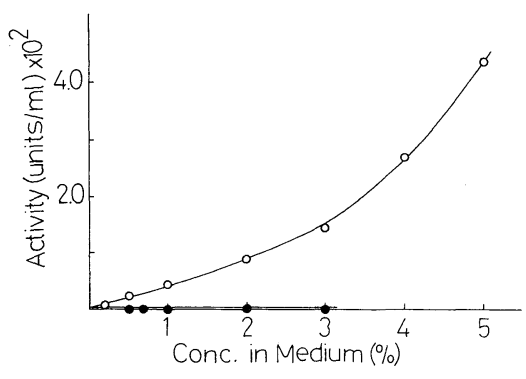

FIG. 2. Effect of Concentration of Sludge Hydrolyzate as Culture Medium on Enzyme Activity.

Enzyme activities were assayed in culture filtrates after 2 day cultivations with various concentrations of sludge hydrolyzate $(O)$ and various concentrations of glucose in medium containing $0.5 \%$ peptone, $0.5 \%$ yeast extract and $0.5 \% \mathrm{NaCl}(\bigcirc)$.

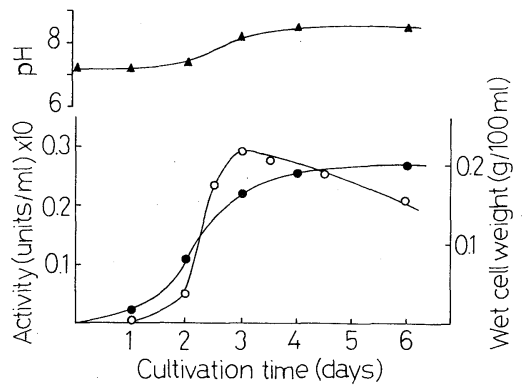

FIG. 3. Time-courses of Growth and Enzyme Production in $2 \%$ Sludge Hydrolyzate Cultures of $F$. oxýsporum.

Wet cell weight $(\boldsymbol{O}), \alpha$-L-fucosidase $(\bigcirc)$ and $\mathrm{pH}(\boldsymbol{\Delta})$ in culture broth.

sludge hydrolyzate used as the sole nutrient source for the culture medium on $\alpha-\mathrm{L}-$ fucosidase activity was investigated. As shown in Fig. 2, the enzyme activity on 2 days' cultivation increased with increasing sludge hydrolyzate concentration in the medium. On the other hand, no activity was found even when the concentration of glucose was increased in a medium containing $0.5 \%$ peptone, $0.5 \%$ yeast extract and $0.5 \%$ $\mathrm{NaCl}$ although the growth of the fungus was very good. We also could not detect any activity when the fungus was cultivated in the active sludge medium without the hydrolysis treatment.

For maximum production of the enzyme in the case of cultivation on $2 \%$ sludge hydrol- yzate medium, we determined the enzyme activity in the culture fluid at different stages of growth of the fungus. As shown in Fig. 3, the enzyme activity was highest at 3 days, when the mycelial weight and $\mathrm{pH}$ of the medium became constant.

\section{Purification of $\alpha$-L-fucosidase \\ Purification was conducted at $5^{\circ} \mathrm{C}$.} Potassium phosphate buffer ( $\mathrm{pH} 7.0$ ) was used throughout the purification procedure.

Crude enzyme in the culture fluid. After 3 days' cultivation with $2 \%$ sludge hydrolyzate, the culture broth in 39 test tubes, each containing $5 \mathrm{ml}$ of medium, was combined and centrifuged at $10,000 \times g$ for $30 \mathrm{~min}$ to remove mycelia and the sludge hydrolyzate precipitates. The resulting brown supernatant was used as the crude enzyme preparation for purification.

Ammonium sulfate fractionation. To about $180 \mathrm{ml}$ of the supernatant, solid ammonium sulfate was added to $75 \%$ saturation. After standing overnight, the precipitate was collected by centrifugation and dissolved in $10 \mathrm{~mm}$ phosphate buffer. The solution was dialyzed overnight against the same buffer.

DEAE-Sephadex A-50 column chromatography. The dialyzed enzyme solution $(40 \mathrm{ml})$ was charged on a DEAE-Sephadex A-50 column $(2.2 \times 17 \mathrm{~cm})$ previously equilibrated with $10 \mathrm{~mm}$ phosphate buffer. The column was thoroughly washed with the same buffer and the enzyme was eluted with a linear gradient of $\mathrm{NaCl}$ of from 0 to $0.8 \mathrm{M}$ in the same buffer. The active fractions were pooled and made to $80 \%$ saturation with ammonium sulfate. The resulting precipitate was dissolved in $1 \mathrm{~mm}$ phosphate buffer and then dialyzed against the same buffer overnight.

Hydroxylapatite column chromatography. The dialyzed enzyme solution $(28 \mathrm{ml})$ was charged on a hydroxylapatite column $(2.3 \times$ $12.5 \mathrm{~cm}$ ) previously equilibrated with $1 \mathrm{~mm}$ phosphate buffer. The column was washed with the same buffer. The adsorbed enzyme was eluted with a linear gradient of phosphate buffer of from $1 \mathrm{~mm}$ to $0.5 \mathrm{M}$. The active fractions were pooled and concentrated 
by the addition of ammonium sulfate to $80 \%$ saturation. The precipitate obtained was dissolved in a small volume of $10 \mathrm{~mm}$ phosphate buffer.

Sephadex G-150 column gel filtration. The concentrated enzyme solution $(4 \mathrm{ml})$ was applied on a Sephadex G-150 column $(1.5 \times 105 \mathrm{~cm})$ previously equilibrated with $10 \mathrm{~mm}$ phosphate buffer and eluted with the same buffer. The active fractions were pooled and precipitated by $80 \%$ saturation with ammonium sulfate. The precipitate was dissolved in $50 \mathrm{~mm}$ phosphate buffer and then dialyzed overnight against the same buffer.

Con A-Sepharose $4 B$ column chromatography. The dialyzed enzyme solution $(6 \mathrm{ml})$ was applied to a column $(0.8 \times 6 \mathrm{~cm})$ of Con ASepharose $4 \mathrm{~B}$ equilibrated with $50 \mathrm{~mm}$ phosphate buffer. After the column had been washed with $50 \mathrm{~mm}$ phosphate buffer and the same buffer containing $0.1 \mathrm{M} \mathrm{NaCl}$, the enzyme was eluted with a linear gradient of 0 to $0.5 \mathrm{M}$ methyl $\alpha$-D-mannoside in the above buffer containing $0.1 \mathrm{M} \mathrm{NaCl}$ (Fig. 4). The active fractions were pooled and concentrated with a collodion bag. The concentrated enzyme solution was used as the purified enzyme.

The results of the enzyme purification are summarized in Table I. The enzyme was purified about 360-fold with a recovery of $20 \%$. The purified enzyme was shown to be almost homogeneous by disc gel electrophoresis on polyacrylamide gel as shown in Fig. 5.

\section{Molecular weight}

The molecular weight of the enzyme was estimated by gel filtration on Sephadex G-200 to be about 80,000 .

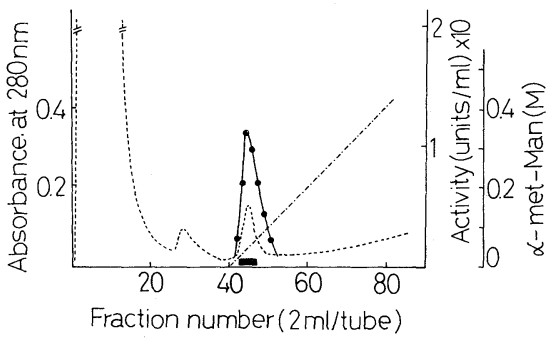

Fig. 4. Con A-Sepharose 4B Column Chromatography of $\alpha$-L-Fucosidase.

The enzyme solution ( $c a .5 .4 \mathrm{mg}$ of protein) was applied to a column $(0.8 \times 6 \mathrm{~cm})$ of Con A-Sepharose $4 \mathrm{~B}$ equilibrated with $50 \mathrm{~mm}$ phosphate buffer ( $\mathrm{pH} 7.0)$. The column was eluted with the same buffer and the buffer containing $0.1 \mathrm{M}$ $\mathrm{NaCl}$, followed by with a linear gradient of methyl $\alpha$-Dmannoside in the same buffer. $\alpha$-L-fucosidase absorbance at $280 \mathrm{~nm} ;-\cdot \cdot \cdot$, methyl $\alpha$-D-mannoside concentration; fractions pooled.

TAble I. Purification of $\alpha$-L-Fucosidase from $F$. oxysporum

\begin{tabular}{|c|c|c|c|c|}
\hline & $\begin{array}{l}\text { Total } \\
\text { protein } \\
(\mathrm{mg})\end{array}$ & $\begin{array}{c}\text { Total } \\
\text { activity } \\
\text { (units) }\end{array}$ & $\begin{array}{c}\text { Specific } \\
\text { activity } \\
\text { (units/mg) }\end{array}$ & $\begin{array}{l}\text { Yield } \\
(\%)\end{array}$ \\
\hline Culture filtrate & 538 & 3.82 & 0.0071 & 100 \\
\hline $\begin{array}{l}\text { Ammonium sulfate } \\
\text { precipitation }\end{array}$ & 376 & 3.68 & 0.0098 & 96 \\
\hline $\begin{array}{l}\text { DEAE-Sephadex A-50 } \\
\text { column chromatography }\end{array}$ & 51 & 2.19 & 0.043 & 57 \\
\hline $\begin{array}{l}\text { Hydroxylapatite } \\
\text { column chromatography }\end{array}$ & 26 & 2.02 & 0.078 & 52 \\
\hline $\begin{array}{l}\text { Sephadex G-150 } \\
\text { column chromatography }\end{array}$ & 5.4 & 1.56 & 0.29 & 40 \\
\hline $\begin{array}{l}\text { ConA Sepharose } 4 \mathrm{~B} \\
\text { column chromatography }\end{array}$ & 0.3 & 0.77 & 2.58 & 20 \\
\hline
\end{tabular}




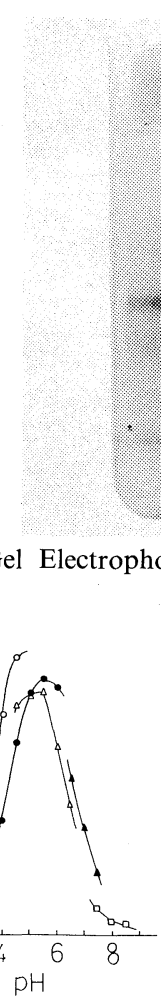

FIG. 5. Disc Gel Electrophoresis of the Purified $\alpha-\mathrm{L}-$ Fucosidase.
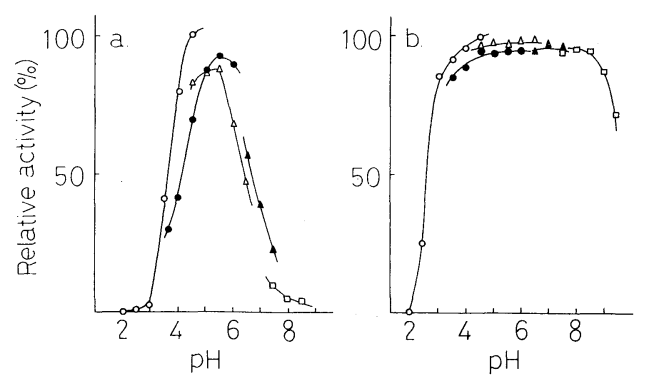

FIG. 6. Effects of $\mathrm{pH}$ on the Activity and Stability of the Enzyme.

(a) Effect of $\mathrm{pH}$ on the activity. The activity at various $\mathrm{pHs}$ was measured under the standard assay conditions $(7.5 \mu \mathrm{g}$ of protein) using various buffer system $(50 \mathrm{~mm})$ and expressed as percentage of the maximum activity.

(b) Effect of $\mathrm{pH}$ on the stability. The enzyme was kept at various $\mathrm{pHs}$ at $4{ }^{\circ} \mathrm{C}$ for 2 days using various buffer systems $(20 \mathrm{~mm})$. The remaining activity was determined by the standard assay method ( $7.5 \mu \mathrm{g}$ of protein) and expressed as a percentage of the original activity.

Buffers: $\bigcirc$, sodium citrate- $\mathrm{HCl} ; \boldsymbol{O}$, acetate; $\triangle$, citrate; $\boldsymbol{\Lambda}$ potassium phosphate; $\square$, Tris- $\mathrm{HCl}$.

\section{Effects of $\mathrm{pH}$ on the activity and stability}

The enzyme showed maximum reactivity in the $\mathrm{pH}$ range of from 4.5 to 5.5 , as shown in Fig. 6a. The enzyme was stable over the wide $\mathrm{pH}$ range of $4 \sim 8$, as shown in Fig. $6 \mathrm{~b}$.

Effects of temperature on the activity and stability

The optimum temperature for the enzyme reaction was about $50^{\circ} \mathrm{C}$ under the standard assay conditions ( $\mathrm{pH} 4.5)$. The heat stability of the enzyme was examined by heating it at various temperatures for $10 \mathrm{~min}$ at $\mathrm{pH}$ 7.0. The enzyme was found to be stable up to about $45^{\circ} \mathrm{C}$.

\section{Effects of various substances on the enzyme activity}

The effects of various metal ions and $\mathrm{SH}$ reagents on the enzyme were investigated. The enzyme ( $10 \mu \mathrm{g}$ protein) was preincubated with $20 \mathrm{~mm}$ of a metal ion or with $10 \mathrm{~mm}$ of a SHreagent in $10 \mathrm{~mm}$ potassium phosphate buffer (pH 7.0) at $37^{\circ} \mathrm{C}$ for $15 \mathrm{~min}$, and then the residual activity was assayed under the standard conditions. Though marked inhibition by $\mathrm{Hg}^{2+}$ was seen, the following ions had no significant effect on the enzyme activity: $\mathrm{Mg}^{2+}$, $\mathrm{Mn}^{2+}, \mathrm{Co}^{2+}, \mathrm{Cu}^{2+}, \mathrm{Zn}^{2+}, \mathrm{Fe}^{2+}$ and $\mathrm{Ca}^{2+}$. $\mathrm{SH}$-reagents such as dithiothreitol, 2-mercaptoethanol, $p$-chloromercuric benzoate and $N$ ethylmaleimide did not have a significant effect on the activity.

\section{Effects of various sugars on the enzyme activity}

The effects of various sugars on the enzyme activity were examined by preincubating the enzyme with $2.5 \mathrm{~mm}$ of each sugar at $37^{\circ} \mathrm{C}$ for $10 \mathrm{~min}$, and then the residual activity was assayed. The enzyme activity was reduced to $85 \%$ and $95 \%$ by L-fucose and D-arabinose, which has a similar structure to L-fucose, respectively. Other sugars including D-fucose and L-arabinose had no effect on the enzyme activity.

\section{Effect of the substrate concentration}

The effect of the substrate concentration on the enzyme activity was examined at $37^{\circ} \mathrm{C}$ using $\quad p$-nitrophenyl $\alpha$-L-fucoside. The Michaelis constant, calculated from a Lineweaver-Burk plot, w.as $8.7 \times 10^{-4} \mathrm{M}$.

\section{Substrate specificity}

The purified enzyme was investigated as to other glycosidase activities by assaying with appropriate $p$-nitrophenyl glycosides: $\beta$-D-and $\beta$-L-fucosides, $\alpha$ - and $\beta$-D-glucosides, $\alpha$ - and $\beta$ D-galactosides, $\alpha$ - and $\beta$-D-mannosides, $\alpha$ - and $\beta$-D- $N$-acetylglucosaminides, $\alpha$ - and $\beta$-D-Nacetylgalactosaminides, and $\beta$-D-glucuronide. 
TABle II. Inhibition of ANTi-H Lectin By $\alpha$-L-Fucosidase-treated Group O SALIVA

Details of the hemagglutination inhibition test were given under Materials and Methods. Figures represent the degree of hemagglutination of $\mathrm{O}$ cells and anti-H lectin. 4 indicates strong hemagglutination and 1 weak hemagglutination. A minus sign indicates no hemagglutination.

\begin{tabular}{|c|c|c|c|c|c|c|c|c|}
\hline & \multicolumn{8}{|c|}{ Dilution of anti-H (Ulex europaeus) } \\
\hline & 1 & 2 & 4 , & 8 & 16 & 32 & 64, & 128, \\
\hline Untreated $\mathrm{O}$ saliva & - & - & - & - & - & - & - & - \\
\hline $\begin{array}{l}0.013 \text { units fucosidase } \\
\text { treated } \mathrm{O} \text { saliva }\end{array}$ & 3 & 1 & - & - & - & - & - & - \\
\hline $\begin{array}{l}0.04 \text { units fucosidase } \\
\text { treated } \mathrm{O} \text { saliva }\end{array}$ & 3 & 3 & 2 & - & - & - & - & - \\
\hline Saline & 4 & 4 & 4 & 4 & 4 & 3 & - & - \\
\hline
\end{tabular}

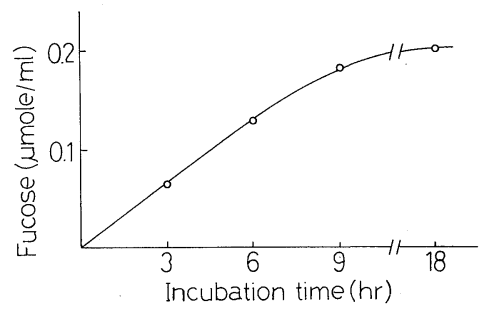

FIG. 7. Liberation of Fucose from Porcine Gastric Mucin by $\alpha$-L-Fucosidase.

Porcine gastric mucin $(30 \mathrm{mg} / \mathrm{ml})$ in $0.05 \mathrm{~m}$ sodium citrate buffer ( $\mathrm{pH} 4.5)$ was incubated with the enzyme solution $(0.007 \mathrm{units} / \mathrm{ml})$ at $37^{\circ} \mathrm{C}$. Aliquots were analyzed for liberated fucose.

The enzyme showed only $\alpha$-L-fucosidase activity, no other glycosidase activities being found.

The ability of the enzyme to split L-fucose off from naturally occurring substrates was examined using porcine gastric mucin. As shown in Fig. 7, the enzyme was able to hydrolyze porcine gastric mucin and liberated L-fucose residues.

Change in the serological activity of a salivary blood group substance caused by the enzyme The $\mathrm{H}$ activity of the secretor in saliva, before and after treatment with the $\alpha-\mathrm{L}$ fucosidase, was examined by means of the hemagglutination inhibition test as shown in Table II. The hemagglutination inhibition test was carried out using the $\mathrm{O}$ cells-anti-H lectin of Ulex europaeus system. Before the treatment, the $\mathrm{H}$ substance of saliva completely inhibited the hemagglutination of $\mathrm{O}$ cells by the anti-H lectin. After enzyme treatment of the salivary blood group substance, the inhibition was significantly reduced. The conversion of the $\mathrm{H}$ substance to an inactive form would be the result of the removal of the terminal linked $\alpha$-L-fucoside of the $H$ group substance by the enzyme.

\section{DISCUSSION}

Recently, as the problem of treatment of surplus sludge has increased, it has been expected that the surplus sludge can be reused in some way. We used it as a medium for microorganisms and tried to obtain useful enzymes produced by the microorganisms. It was reported that active sludge contains rhamnose, fucose, arabinose, xylose, mannose, galactose and glucose, as neutral sugar components. ${ }^{22,23)}$ These sugars seemed to exist in the form of complex carbohydrates. We found various glycosidases produced by many microorganisms grown on a medium of active sludge hydrolyzate (data not shown). This may indicate that the microorganisms produced various glycosidases in order to utilize the sludge hydrolyzate. 
During the progress of our study on sludge, a strain of Fusarium oxysporum isolated from soil was found to produce a unique $\alpha$-Lfucosidase in the culture fluid only when it was cultivated on the active sludge hydrolyzate medium. $\alpha$-L-Fucosidase is very useful for elucidating the structures of glycoconjugates which have L-fucose as a nonreducing terminal residue with binding through an $\alpha$-glycosidic linkage. It was reported by $\mathrm{Bahl}^{5)}$ that $\alpha-\mathrm{L}-$ fucosidase can be broadly classified into two groups: those which are specific for the Lfucopyranosyl group and the $\alpha$-anomeric configuration of the fucosidic linkage, and those which require, in addition, the presence of the specific $\alpha-1,2$ linkage of fucose to the next sugar residue in the carbohydrate chain. The former class of fucosidases hydrolyzes alkyl or aryl fucosides and also liberates fucose from the nonreducing ends of oligo- or polysaccharide chains, but do not hydrolyze blood group substances. The fucosidases of mammalian tissues, ${ }^{8 \sim 10)}$ abalone $^{11)}$ and a marine gastropod $^{12)}$ which are able to hydrolyze $p$ nitrophenyl $\alpha$-L-fucoside belong to this class. The latter class of fucosidases does not hydrolyze alkyl or aryl fucosides, but hydrolyzes only specific $\alpha$-1,2-fucosidic linkages in oligoand polysaccharides. Microorganisms ${ }^{3 \sim 6)}$ and almond $^{7)}$ fucosidases show this type of specificity. Although they do not hydrolyze $p$ nitrophenyl $\alpha$-L-fucoside, they have attracted much attention because of their specificity as to the hydrolysis of blood group substances having specific fucosyl linkages. Their activities were assayed on the basis of the amount of fucose liberated from natural substrates such as blood group substances by using a Conway chamber, gas-liquid chromatography or a serological method. The enzyme we found could hydrolyze $p$-nitrophenyl $\alpha$-L-fucoside and also liberated fucose from porcine gastric mucin and a blood group substance in saliva. So, we can easily determine the enzyme by using $p$-nitrophenyl $\alpha$-L-fucoside as a substrate. Moreover, since this fungal enzyme is an extracellular one, in contrast with the Bacillus and Trichomonas enzymes which are intracellular, ${ }^{3,6)}$ it is also easier to obtain it. This paper is the first report of such a novel enzyme being found in a microorganism.

We concluded that this fungal enzyme is an inducible one, on consideration of some information on the catabolite repression by glucose (the detailed data are not shown). This paper may be the first report concerning an inducible $\alpha$-L-fucosidase. However, some properties of this enzyme except substrate specificity, such as optimum $\mathrm{pH}$ and stability, were not so different from those of the two types of enzyme mentioned above. A detailed study on the substrate specificity and the induction of enzyme production will be reported in the next paper.

Acknowledgment. We express our thanks for the support and cooperation of Kizakura Syuzoh Co., Ltd. in this study.

\section{REFERENCES}

1) A. Gottschalk, "Glycoproteins," Elsevier Publishing Co., Amsterdam, 1972, pp. 546, 627, 821, 836.

2) J. F. Kennedy and C. A. White, "Bioactive Carbohydrates," Ellis Horwood Ltd., West Sussex, 1983, pp. 42, 136, 150.

3) W. M. Watkins, Biochem. J., 71, 261 (1959).

4) D. Aminoff and K. Furukawa, J. Biol. Chem., 245, 1659 (1970).

5) O. P. Bahl, J. Biol. Chem., 245, 299 (1970).

6) N. Kochibe, J. Biochem., 74, 1141 (1973).

7) A. Kobata, "Methods in Enzymology," Vol. 83, ed. by S. P. Colowick and N. O. Kaplan, Academic Press Inc., New York, 1983, p. 625.

8) G. A. Levvy and A. McAllen, Biochem. J., 80, 435 (1961).

9) H. B. Bosmann and B. A. Hemsworth, Biochim. Biophys. Acta, 242, 152 (1971).

10) D. J. Opheim and O. Touster, J. Biol. Chem., 252, 739 (1977).

11) K. Tanaka, T. Nakano, S. Noguchi and W. Pigman, Arch. Biochem. Biophys., 126, 624 (1968).

12) M. Nishigaki, T. Muramatsu, A. Kobata and K. Maeyama, J. Biochem., 75, 509 (1974).

13) J. Borooah, D. H. Leaback and P. G. Walker, Biochem. J., 78, 106 (1961).

14) A. Tiselius, S. Hjerten and O. Levin, Arch. Biochem. Biophys., 65, 132 (1956).

15) O. H. Lowry, N. J. Rosebrough, A. L. Farr and R. J. Randall, J. Biol. Chem., 193, 265 (1951).

16) A. K. Bhattacharyya and D. Aminoff, Anal. Biochem., 14, 278 (1966). 
17) B. J. Davis, Ann. N. Y. Acad. Sci., 121, 404 (1964).

18) P. Andrews, Biochem. J., 91, 222 (1964).

19) C. Booth, "The genus Fusarium," Commonwealth Mycological Institute, 1971, p. 130.

20) W. Gerlach and H. Nirenberg, "The genus Fusarium-a Pictorial Atlas," Biologisch Bundesanstalt für Land- und Forstwirtschaft Institute für Mikrobiologie, Berlin-Dahlem, Berlin, 1982, p. 345.

21) P. E. Nelson, T. A. Toussoun and W. F. O. Marasas, "Fusarium Species: An Illustrated Manual for Identification," The Pennsylvania State University Press,
University Park, 1983, p. 142.

22) T. Tochikura, T. Yano, M. Hatanaka, S. Ashida, K. Sakai, K. Yamamoto, T. Tachiki and H. Kumagai, Annual Report of Research for Environment Science supported by the Department of Education, 1981, p. 26.

23) K. Kakii, T. Shiragashi and M. Kuriyama, Abstracts of Papers, Annual Meeting of the Society of Fermentation Technology, Japan, Osaka, November 1983 , p. 86 . 